hospital. This issue can be obscured by the occasional mild case-commoner in younger children and smaller bones, as described by Bremner and Neligan (1958)-in which delay in terms of days or even weeks may be relatively harmless. In the much commoner severe cases in older children the target period for admission is the first 48 hours after the start of the pain. Then an effective antibiotic will produce a complete cure without any need for local intervention in about $90 \%$ of cases (present series plus 41 such cases reported by Bremner and Neligan in 1958). Even up to 96 hours after the onset a relatively short course of antibiotic treatment, usually supplemented by removal of pus, will result in a relatively quick return to full activity. We know that in three-quarters of cases the family doctor has seen the patient within the first of these target periods, and in almost all within the second.

When there is delay in diagnosis we have evidence (Bremner and Neligan, 1958) that the commonest cause is the doctor's failure to appreciate that there is both a systemic illness and a local lesion in a bone, near but not in a joint, giving rise to the diagnostic sign of " one-finger tenderness." Any suspicion of osteitis should be the indication for immediate referral to hospital. The diagnosis may often be difficult, and should be confirmed by the most experienced observer available; only in hospital can the fullest possible bacteriological information and the most effective regime of antibiotic administration be made available, and local surgical intervention may become necessary at any time. It matters little to whom the case is referred, so long as all those who may be primarily concerned in the casualty, paediatric, and orthopaedic departments are fully alert to the requirements of diagnosis and treatment, and ready to call for help when required. In view of the nature of the disease some form of collaboration between orthopaedic surgeon and paediatrician seems desirable (Annan and Sweetnam, 1962).

We believe that such collaboration, in support of effective action by the family doctors, who are the first to see these patients, can still produce satisfactory results in the great majority in spite of the emergence of penicillin-resistant organisms. The results of the present investigation support this view and underline the importance of immediate referral to hospital, followed by purposeful use of the most effective antibiotics currently available, and prompt removal of any pus which forms in the subperiosteal space.

\section{Summary}

Reference to the recent literature on the subject suggests that there is widespread disagreement about the correct treatment of acute osteitis in children, and that the incidence of unsatisfactory results is about $30 \%$. Both these very disturbing findings appear to be attributable to the dearth of planned studies of suitably selected cases.

We report the findings of a retrospective study of the methods and results of treatment in a consecutive series of 38 cases of severe acute osteitis in older children admitted to hospital during 1957-63, and selected in accordance with defined clinical criteria. Effective antibiotic treatment was started as soon as possible, and pus which formed in the subperiosteal space was removed (by aspiration) as soon as the indication arose. Results were satisfactory in $95 \%$ of cases ; the two unsatisfactory cases in which sequestra formed were caused by penicillin-resistant organisms treated with chlortetracycline. It seems likely that the use of methicillin or cloxacillin in such cases should reduce the incidence of unsatisfactory results.

The importance of achieving the earliest possible diagnosis and admission to hospital is illustrated by reference to the higher incidence of operative intervention if effective treatment is delayed till after the first 48 hours, and the longer duration both of antibiotic treatment and of disability in cases admitted after the first 96 hours.

We would like to thank our colleagues, under whose care the patients were admitted, for permission to report these cases, and particularly Mr. A. E. Bremner who performed the two sequestrectomies.

\section{REFERENCES}

Annan, J. H., and Sweetnam, W. P. (1962). Brit. med. F., 1, 1693. Bremner, A.' E., and Neligan, G. A. (1958). Chapter on "Pyogenic Osteitis" in Recent Advances in Paediatrics, 2nd ed., edited by D. M. T. Gairdner. Churchill, London. D. M. T. Gairdner. Churchill, London.

Gilmour, W. N. (1962). f. Bone ft Surg., 44B, 841.

Harris, N. H. (1962). Brit. med. f., 1, 1440.

Mann, T. S. (1963). Ibid., 2, 1561.

Neligan, G. A., and Warrick, C. K. (1953). F. Fac. Radiol. (Lond.), 5, 112.

Pappworth, S. (1962). Brit. med. f., 2, 338.

Trueta, J., and Morgan, J. D. (1954). Brit. F. Surg., 41, 449.

\footnotetext{
* Research Associate, Fairleigh-Dickinson University, Madison, New Jersey.

† Supervising Biochemist, Atherosclerosis Research Group, St. Vincent's Hospital, Montclair, New Jersey.

$\ddagger$ Director, Atherosclerosis Research Group, St. Vincent's Hospital, Montclair, New Jersey.
}

Studies on the influence of calcium in the digestion of lipids were not restricted to man. A similar effect with long-chain triglycerides and hydrogenated fats was found in rats (Cheng et al., 1949 ; Carroll and Richards, 1958), cattle (Ward and Reid, 1948), chickens (Fedde et al., 1960), and dogs (Steudel, 1944, 1947).

Since calcium has been reported to decrease lipid absorption, it was of interest to determine the effect of this alteration upon human serum lipids. This is a preliminary report of a study to assess the effects of ingested supplemental calcium upon serum lipids, including cholesterol, triglycerides, and phospholipids. 


\section{Materials and Methods}

The feeding tests utilized were divided into two phases. The first, a feasibility test, was run on four ambulatory clinically healthy males, and $2.66 \mathrm{~g}$. of calcium in the form of calcium carbonate was fed mixed with the three daily meals. A four-day base period was followed by a four-day calcium ingestion period. The diets for both periods were identical and consisted of $40 \%$ of calories as lipids, primarily of animal origin.

The second phase consisted of a 21-day feeding experiment in which 13 volunteers, aged 30-50, of both sexes, ingested $0.89 \mathrm{~g}$. of calcium in addition to the calcium contained in the foods. In this phase a three-week control period was followed by a three-week period during which the additional calcium was ingested. Detailed dietary records were kept during both periods. The daily diets contained $40 \%$ fat calories and $0.89 \mathrm{~g}$. of calcium, and were designed so that there was no significant weight change during the study period. In all cases base serum lipid values were the mean of duplicate analyses run on at least three consecutive weeks.

All lipid determinations were conducted weekly on 14-hour post-absorptive serum. Serum cholesterol was determined by Anderson and Keys's (1956) modification of the procedure of Abell et al. (1952), S.D. $4 \mathrm{mg} . / 100 \mathrm{ml}$. The serum triglycerides were estimated on an extract of serum (Folch et al., 1957) by a modification of the method of Van Handel and Zilversmit (1957), S.D. $4.5 \mathrm{mg} . / 100 \mathrm{ml}$. Phospholipids were determined by the Bartlett (1959) procedure, S.D. $5 \mathrm{mg} . / 100 \mathrm{ml}$. Faecal dry matter was assayed by drying in vacuo at $60^{\circ} \mathrm{C}$. to constant weight. Faecal total lipids were isolated by repetitive diethyl ether extraction of acidulated (dilute hydrochloric acid) dried faecal matter and estimated by evaporation of the solvent and drying in a vacuum desiccator.

\section{Results}

The results of the preliminary feeding experiments are shown in Table I. A mean decrease of $14 \mathrm{mg} . / 100 \mathrm{ml}$. (S.D. 2.69) was demonstrable in the serum cholesterol within 96 hours when $2.66 \mathrm{~g}$. of calcium over the normal daily intake of $0.71 \mathrm{~g}$./day was ingested daily. Data on faecal lipids of three of these subjects is given in Table II. A mean increase in faecal lipid

\begin{tabular}{|c|c|c|c|c|}
\hline \multirow{2}{*}{ Subject } & \multirow{2}{*}{ Age } & \multicolumn{3}{|c|}{ Serum Choles terol (mg./100 ml.) } \\
\hline & & Control Value & After Calcium & Difference \\
\hline \multirow[t]{2}{*}{$\begin{array}{l}1 \\
2 \\
3 \\
4\end{array}$} & $\begin{array}{l}39 \\
20 \\
40 \\
21\end{array}$ & $\begin{array}{l}222 \\
197 \\
193 \\
198\end{array}$ & $\begin{array}{l}205 \\
188 \\
184 \\
176\end{array}$ & $\begin{array}{r}-17 \\
-9 \\
-9 \\
-22\end{array}$ \\
\hline & & \multicolumn{2}{|c|}{ Mean decrease (S.D.) } & $14(2 \cdot 69)$ \\
\hline
\end{tabular}

TABLE II.-Effect of Oral Dosage With $2.66 \mathrm{~g}$. of Calcium as Carbonate

\begin{tabular}{|c|c|c|c|c|c|c|}
\hline \multirow{3}{*}{ Subject } & \multicolumn{3}{|c|}{ Daily Dry Matter Excretion } & \multicolumn{3}{|c|}{ Daily Total Faecal Lipids } \\
\hline & \multirow{2}{*}{$\begin{array}{c}\text { Control } \\
\text { Value } \\
\text { (g.) }\end{array}$} & \multicolumn{2}{|c|}{ During Calcium } & \multirow{2}{*}{$\begin{array}{c}\text { Control } \\
\text { Value } \\
\text { (g.) }\end{array}$} & \multicolumn{2}{|c|}{ During Calcium } \\
\hline & & Dosage (g.) & Increase & & Dosage (g.) & Increase \\
\hline $\begin{array}{l}1 \\
2 \\
3\end{array}$ & $\begin{array}{l}26 \cdot 8 \\
25 \cdot 0 \\
30 \cdot 1\end{array}$ & $\begin{array}{l}35 \cdot 7 \\
32 \cdot 9 \\
42 \cdot 6\end{array}$ & $\begin{array}{l}33.2 \% \\
31.6 \% \\
41.5 \%\end{array}$ & $\begin{array}{l}6.67 \\
4.52 \\
7.36\end{array}$ & $\begin{array}{c}12 \cdot 38 \\
9 \cdot 21 \\
13 \cdot 5\end{array}$ & $\begin{array}{r}85.6 \% \\
103.8 \% \\
83.4 \%\end{array}$ \\
\hline
\end{tabular}

excretion of $90.9 \%$ (S.D. 3.1) is shown during the period of calcium ingestion.

The results of serum lipid determinations from a feeding experiment on 13 subjects, both male and female, in which $0.89 \mathrm{~g}$. of calcium over the normal daily dietary calcium intake was ingested for 21 days, are presented in Table III. The mean serum cholesterol decrease was $15 \mathrm{mg} . / 100 \mathrm{ml}$. (S.D. 4.9). These results show a high degree of significance $(P<0.01)$. Dividing subjects according to their base serum cholesterol levels gave the expected results. Normocholesterolaemics (base serum cholesterol below $220 \mathrm{mg} . / 100 \mathrm{ml}$.) showed the smallest mean

TABLE III.-Effects of Increased Calcium Intake on Serum Lipids-21TABLE III.-Effects of Increased Calcium Intake on Serum Lipids

\begin{tabular}{|c|c|c|c|c|c|c|c|c|}
\hline \multirow{2}{*}{$\begin{array}{l}\text { Sub- } \\
\text { ject }\end{array}$} & \multirow{2}{*}{$\begin{array}{l}\text { Age } \\
\text { and } \\
\text { Sex }\end{array}$} & \multirow{2}{*}{$\begin{array}{l}\text { Form } \\
\text { of } \\
\text { Calcium }\end{array}$} & \multicolumn{3}{|c|}{$\begin{array}{c}\text { Total Serum Cholesterol } \\
\text { (mg./100 ml.) }\end{array}$} & \multicolumn{3}{|c|}{$\begin{array}{c}\text { Serum Triglycerides } \\
\text { (mg./100 ml. as Tripalmitin) }\end{array}$} \\
\hline & & & $\begin{array}{l}\text { Control } \\
\text { Value } \\
\end{array}$ & $\begin{array}{c}\text { After } \\
\text { Calcium }\end{array}$ & Diff. & $\begin{array}{l}\text { Control } \\
\text { Value }\end{array}$ & $\begin{array}{c}\text { After } \\
\text { Calcium }\end{array}$ & Diff. \\
\hline \multirow[t]{2}{*}{\begin{tabular}{r|}
5 \\
6 \\
7 \\
8 \\
9 \\
10 \\
\end{tabular}} & $\begin{array}{lc}21 & M \\
21 & M \\
41 & M \\
40 & F \\
40 & F \\
21 & M\end{array}$ & $\begin{array}{c}\text { Gluconate } \\
\text { ", } \\
\text { Carbonate } \\
\text { ", }\end{array}$ & $\begin{array}{l}182 \\
184 \\
188 \\
168 \\
199 \\
203\end{array}$ & $\begin{array}{l}181 \\
176 \\
167 \\
172 \\
201 \\
214 \\
\end{array}$ & $\begin{array}{r}-1 \\
-8 \\
-21 \\
+4 \\
+2 \\
+11\end{array}$ & $\begin{array}{r}150 \\
113 \\
120 \\
103 \\
96 \\
107\end{array}$ & $\begin{array}{r}100 \\
95 \\
110 \\
102 \\
67 \\
97 \\
\end{array}$ & $\begin{array}{r}-50 \\
-18 \\
-10 \\
-1 \\
-29 \\
-10\end{array}$ \\
\hline & & & & $\begin{array}{l}\text { Mean } \\
\text { S.D. }\end{array}$ & $\begin{array}{r}-2 \cdot 2 \\
4 \cdot 7 \\
\end{array}$ & & $\begin{array}{l}\text { Mean } \\
\text { S.D. }\end{array}$ & $\begin{array}{r}-19 \cdot 7 \\
7 \cdot 2 \\
\end{array}$ \\
\hline \multirow[t]{2}{*}{$\begin{array}{l}11 \\
12 \\
13 \\
14 \\
15\end{array}$} & $\begin{array}{ll}37 & M \\
37 & M \\
38 & M \\
45 & M \\
21 & F\end{array}$ & $\begin{array}{c}\text { Gluconate } \\
\text { Carbonate } \\
\text { ", }\end{array}$ & $\begin{array}{l}253 \\
247 \\
241 \\
251 \\
236\end{array}$ & $\begin{array}{l}228 \\
236 \\
224 \\
228 \\
184\end{array}$ & $\begin{array}{l}-25 \\
-11 \\
-17 \\
-23 \\
-42\end{array}$ & $\begin{array}{l}146 \\
180 \\
158 \\
240 \\
114\end{array}$ & $\begin{array}{l}148 \\
144 \\
127 \\
218 \\
100\end{array}$ & $\begin{array}{l}+2 \\
-36 \\
-31 \\
-22 \\
-14\end{array}$ \\
\hline & & & & $\begin{array}{l}\text { Mean } \\
\text { S.D. }\end{array}$ & $\begin{array}{r}-23 \cdot 6 \\
5 \cdot 2 \\
\end{array}$ & & $\begin{array}{l}\text { Mean } \\
\text { S.D. }\end{array}$ & $\begin{array}{r}-20 \cdot 2 \\
6 \cdot 7 \\
\end{array}$ \\
\hline \multirow[t]{3}{*}{$\begin{array}{l}16 \\
17 \\
\end{array}$} & $\begin{array}{l}34 M \\
35 M\end{array}$ & $\begin{array}{l}\text { Gluconate } \\
\text { Carbonate }\end{array}$ & $\begin{array}{l}338 \\
330 \\
\end{array}$ & $\begin{array}{l}290 \\
309 \\
\end{array}$ & $\begin{array}{l}-48 \\
-21 \\
\end{array}$ & $\begin{array}{l}272 \\
242 \\
\end{array}$ & $\begin{array}{l}188 \\
127 \\
\end{array}$ & $\begin{array}{r}-84 \\
-115 \\
\end{array}$ \\
\hline & & & & $\begin{array}{l}\text { Mean } \\
\text { S.D. }\end{array}$ & $\begin{array}{r}-34 \cdot 5 \\
13 \cdot 5 \\
\end{array}$ & & $\begin{array}{l}\text { Mean } \\
\text { S.D. }\end{array}$ & $\begin{array}{r}-99.5 \\
15.5 \\
\end{array}$ \\
\hline & & & $\begin{array}{l}\text { Overal } \\
\text { S.D. }\end{array}$ & 11 mean & $\begin{array}{r}-15 \cdot 4 \\
4.9\end{array}$ & $\begin{array}{l}\text { Overa } \\
\text { S.D. }\end{array}$ & all mean & $\begin{array}{r}-32 \cdot 15 \\
8 \cdot 88\end{array}$ \\
\hline
\end{tabular}

drop, $2.2 \mathrm{mg} . / 100 \mathrm{ml}$. (S.D. 4.7) and in some cases exhibited an elevation in serum cholesterol. These elevations were within the normal weekly variation in serum cholesterol. The mean cholesterol decrease of subjects whose base cholesterol fell between 220 and $260 \mathrm{mg} . / 100 \mathrm{ml}$. was $23.6 \mathrm{mg}$. $/ 100 \mathrm{ml}$. (S.D. 5.2). These decreases were significantly greater than the normal weekly variation in base serum cholesterol of these subjects. The two hypercholesterolaemics (above $260 \mathrm{mg} . / 100 \mathrm{ml}$.) showed the largest mean decrease in serum cholesterol, $34.5 \mathrm{mg}$./ $100 \mathrm{ml}$. (S.D. 13.5).

Examination of the serum triglycerides, with the subjects divided into the same groups as determined by baseline cholesterol levels (Table III), indicated a decrease in serum triglycerides in 11 of the 13 subjects. In two subjects the serum triglycerides remained essentially unchanged. Hypertriglyceridaemic subjects (base value over $150 \mathrm{mg} . / 100 \mathrm{ml}$.) exhibited the more dramatic change, with a mean decrease of $56.3 \mathrm{mg}$./ $100 \mathrm{ml}$. (S.D. 14.7) as compared with the normotriglyceridaemics, with a mean decrease of $11.4 \mathrm{mg} . / 100 \mathrm{ml}$. (S.D. 3.95). The difference between the means is highly significant, $\mathrm{P}<0.02$ (S.D. 15.2).

No significant difference was observed in serum phospholipids between the control and treatment period in the subjects studied.

During the 21-day feeding experiment serum lipid determinations were run weekly, although only the base and 21-day values are reported in Table III. It was noted that the major decrease occurred within the first week and that during the subsequent two weeks the lower serum lipid levels were essentially maintained.

\section{Discussion}

During fat digestion ester linkage hydrolysis occurs in the intestinal tract, producing non-esterified fatty acids. In the presence of calcium insoluble calcium soaps are formed and excreted in the faeces. The increased faecal fat excretion reported here is in agreement with that reported by Drenick (1961) and others. 
Substitution of gluconate for carbonate as the anion in the calcium salt resulted in no significant difference in metabolic effect, as was anticipated from the results of Patton and Sutton (1952). The change from carbonate to gluconate was attempted because carbonate caused a degree of constipation and abdominal distress which was absent when gluconate was employed. The gluconate, however, because of the higher molecular weight, requires considerably more of the salt to achieve the same calcium level, presenting the problem of larger numbers of tablets to be ingested.

The lowering of serum cholesterol and triglycerides by calcium is interesting from two points of view. First, Wells and Cooper (1958) reported that calcium inhibited cholesterol absorption in rats in the presence of dietary fat. Calcium was also reported to be hypocholesterolaemic in rabbits (Iacono et al., 1960). This might in part explain some of the hypocholesterolaemic activity of calcium in that absorption of exogenous cholesterol may have been inhibited. The second reason for interest in the hypolipaemic action of calcium was the repeated reports of a negative relation between mortality from cardiovascular disease and the hardness of drinking-water (Schroeder, 1960a, 1960b ; Morris et al., 1961). Since calcium is the major cation associated with water hardness, it was not unexpected that a similar negative correlation was found between water calcium-ion concentration and cardiovascular disease mortality.

Studies are being conducted into the mechanism of the hypolipaemic effect of calcium and upon the effects of calcium ingestion upon tissue lipids. It is anticipated that this preliminary study will be expanded to examine the effects of dietary calcium on larger numbers of people, particularly young males with electrocardiographically proved myocardial infarctions, in order to ascertain whether a significant decrease in morbidity and mortality could be attained in this way.

\section{Summary}

Increased calcium ingestion by subjects of both sexes who were free of clinical coronary heart disease caused a significant decrease in both serum cholesterol and serum triglyceride levels. Both faecal dry matter and total faecal lipids were increased. The exact mechanism of the hypolipaemic action of calcium still requires clarification.

We are indebted to Mr. William Boyko and Mrs. J. S. Breuchaud, who assisted in the experiments. This investigation was supported in part by the Morris County Heart Association, the DeeringMilliken Foundation, and Research Grant No. H-5905 from the National Heart Institute, United States Public Health Service.

\section{REFERENCES} Abell, L. L., Levy, B. B., Brodie, B. B., and Kendall, F. E. (1952). J.

Anderson, J. T., and Keys, A. (1956). Clin. Chem., 2, 145.

Aub,' J. C., and Farquharson, R. F. (1932). F. clin. Invest., 11, 235.

Bartlett, G. R. (1959). 7. biol. Chem., 234, 466.

Carroll, K. K., and Richards, J. F. (1958). F. Nutr., 64, 411.

Cheng, A. L. S., Morehouse, M. G., and Deuel, H. J., iun. (1949) Ibid., 37, 237

Drenick, E. J. (1961). Gastroenterology, 41, 242.

Fedde, M. R., Waibel, P. E., and Burger, R. E. (1960). f. Nutr., 70, 447. Folch, J., Lees, M., and Sloane Stanley, G. H. (1957). F. biol. Chem. 226, 497.

Givens, M. H. (1917). Ibid., 31, 441.

Iacono, J. M., Mueller, J. F., and Ammerman, C. B. (1960). Fed. Proc., 19,15 .

Morris, J. N., Crawford, M. D., and Heady, J. A. (1961). Lancet, 1,

Patton, M. B., and Sutton, T. S. (1952). F. Nutr., 48, 443.

Schroeder, H. A. (1960a). f. Amer. med. Ass., 172, 1902.

- (1960b). F. chron. Dis., 12, 586.

Steudel, H. (1944). Frnährungsforschung, 9, 37

- (1947). Med. Klin., 42, 142.

Van Handel, E., and Zilversmit, D. B. (1957). F. Lab. clin. Med., 50 152.

Ward, G. M., and Reid, J. T. (1948). F. Nutr., 35, 249.

Wells, W. W., and Cooper, S. B. (1958). Arch. Biochem., 75, 273.

Yacowitz, H. (1962). Fed. Proc., 21, 258.

\title{
Indomethacin: Studies of Absorption and of the Use of Indomethacin Suppositories
}

\author{
L. P. J. HOLT,* M.B., M.R.C.P., M.R.C.P.ED. ; C. F. HAWKINS, † M.D, F.R.C.P.
}

Indomethacin, a new drug for treating arthritic disorders, was introduced for clinical trial in 1962. It is chemically unrelated to either corticosteroids or other anti-inflammatory compounds, and has an indole structure within its formula [1(p-chlorobenzoyl)-5-methoxy-2-methylindol-3-acetic acid].

Although anti-inflammatory activity can be demonstrated in animals (Winter, Risley, and Nuss, 1963), this effect has not been conclusively shown in man, though measurable reduction in the finger-swellings of patients with rheumatoid arthritis, as measured by jeweller's rings, occurs (Hart and Boardman, 1963). Other parameters of inflammation such as the erythrocyte sedimentation rate are unaffected.

The reports of controlled clinical trials (Hart and Boardman, 1963 ; Wanka, Jones, Wood, and Dixon, 1964 ; Percy, Stephenson, and Thompson, 1964) prove that this drug relieves symptoms in different arthritic disorders such as rheumatoid arthritis, osteoarthrosis, ankylosing spondylitis, and gout. Unfortunately, like other analgesic and anti-inflammatory

* Medical Registrar, Queen Elizabeth Hospital, Birmingham.

† Consultant Physician, United Birmingham Hospitals; Lecturer in Clinical Medicine, University of Birmingham. agents, it carries the risk of gastro-intestinal irritation. The tablets which were used originally led to peptic ulceration in some patients (Catoggio, Centurion, Alberti, Roldan, and Canepa, 1964 ; Kelly, 1964 ; Lövgren and Allander, 1964 ; Robinson, 1964 Wanka et al., 1964), and anorexia, nausea, vomiting, dyspepsia, and diarrhoea have also occurred. Other side-effects have involved the central nervous system (headache, giddiness, faintness, mental changes, drowsiness, and blurring of vision).

The introduction of gelatin capsules containing powdered indomethacin and the prescribing of smaller doses have led to a decreased incidence of side-effects. However, we thought it important to assess its absorption from the rectum in the hope that suppositories could be used for patients suffering from peptic ulcers, for those who develop gastric intolerance to the drug, and for patients who require larger doses than can safely be given by mouth.

\section{Materials and Methods}

Of 40 patients studied, 34 suffered from rheumatoid arthritis, 3 from osteoarthrosis, 2 from ankylosing spondylitis, and 1 